\title{
HealthAffairs
}

At the Intersection of Health, Health Care and Policy

Cite this article as:

Henry G. Grabowski, Margaret Kyle, Richard Mortimer, Genia Long and Noam Kirson Evolving Brand-Name And Generic Drug Competition May Warrant A Revision Of The Hatch-Waxman Act

Health Affairs, 30, no.11 (2011):2157-2166

doi: $10.1377 /$ hlthaff.2010.0270

The online version of this article, along with updated information and services, is available at:

http://content.healthaffairs.org/content/30/11/2157.full.html

For Reprints, Links \& Permissions:

http://healthaffairs.org/1340_reprints.php

E-mail Alerts : http://content.healthaffairs.org/subscriptions/etoc.dtl

To Subscribe: http://content.healthaffairs.org/subscriptions/online.shtml

Health Affairs is published monthly by Project HOPE at 7500 Old Georgetown Road, Suite 600, Bethesda, MD 20814-6133. Copyright (C 2011 by Project HOPE - The People-to-People Health Foundation. As provided by United States copyright law (Title 17, U.S. Code), no part of Health Affairs may be reproduced, displayed, or transmitted in any form or by any means, electronic or mechanical, including photocopying or by information storage or retrieval systems, without prior written permission from the Publisher. All rights reserved. 


\section{Evolving Brand-Name And Generic Drug Competition May Warrant A Revision Of The Hatch-Waxman Act}

ABSTRACT The evolution of pharmaceutical competition since Congress passed the Hatch-Waxman Act in 1984 raises questions about whether the act's intended balance of incentives for cost savings and continued innovation has been achieved. Generic drug usage and challenges to brand-name drugs' patents have increased markedly, resulting in greatly increased cost savings but also potentially reduced incentives for innovators. Congress should review whether Hatch-Waxman is achieving its intended purpose of balancing incentives for generics and innovation. It also should consider whether the law should be amended so that some of its provisions are brought more in line with recently enacted legislation governing approval of so-called biosimilars, or the corollary for biologics of generic competition for small-molecule drugs.

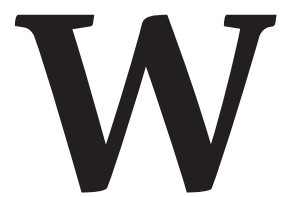
ith the Drug Price Competition and Patent Term Restoration Act of 1984 , commonly known as the Hatch-Waxman Act, Congress created the foundation for the modern generic drug industry in the United States. In enacting the legislation, Congress aimed to increase generic competition while balancing the resulting cost savings with sufficient incentives to encourage the continued innovation of new drugs. By 2009, 75 percent of all US prescriptions were for generic drugs. ${ }^{1}$

We consider in this paper how generic competition and market exclusivity for new brandname drugs-that is, the time between the launch of the brand-name version and its first generic competitor-have evolved under HatchWaxman. We also examine evolving trends in another far-reaching feature of the act, so-called Paragraph IV patent challenges, in which generic manufacturers claim patent invalidity or assert noninfringement before patents held by brand-name drug innovators expire.

Prior to the Hatch-Waxman Act, generic manufacturers were required to submit safety and efficacy data on their products to gain market approval by the Food and Drug Administration (FDA). Such data on the brand-name versions of drugs are protected as trade secrets. Thus, the generic manufacturer generally had to duplicate many of the brand-name manufacturer's trials, which could take several years and millions of dollars to complete. ${ }^{2}$ As a result, it was estimated that in 1983 only 35 percent of the best-selling off-patent drugs faced generic competition. ${ }^{2}$

Hatch-Waxman facilitated generic drugs' entry into the market in several ways. First, it established an Abbreviated New Drug Application process. Under this process, generic manufacturers needed only to demonstrate that their product had "bioequivalence" to its brand-name counterpart. They did not have to conduct clinical trials on the efficacy or safety of their products. Generic manufacturers also received a research exemption for bioequivalence studies, allowing them to undertake research on the innovator's patents prior to expiration without infringing them.

Second, Hatch-Waxman created incentives for generic manufacturers to challenge brand-name patents before they expired and processes through which they could do so. In one of these
DOI: $10.1377 /$ hlthaff.2010.0270 HEALTH AFFAIRS 30 , NO. 11 (2011): 2157-2166 (C2011 Project HOPEThe People-to-People Health Foundation, Inc
Henry G. Grabowski (grabow@ econ.duke.edu) is a professor emeritus of economics and director of the Program in Pharmaceutical and Health Economics at Duke University, in Durham, North Carolina.

Margaret Kyle is a professor of management at the Toulouse School of Economics, in France.

Richard Mortimer is a vice president at Analysis Group, in Boston, Massachusetts.

Genia Long is managing principal at Analysis Group.

Noam Kirson is a manager at Analysis Group. 
processes, known as a "Paragraph IV filing," the generic manufacturer notifies the FDA that it claims its generic product does not infringe on a patent on the brand-name drug, or that a patent held on the brand-name drug is not enforceable. The manufacturer of the brand-name drug then has forty-five days to file a patent infringement action against the generic company.

After the suit has been filed, the FDA cannot approve the generic company's application until the company prevails in court or through settlement, or until a thirty-month stay expires, whichever comes first. But if the generic manufacturer wins the lawsuit, and the FDA approves its application, the manufacturer is granted a 180-day period of exclusivity, during which its drug is the only generic version allowed on the market.

To balance these provisions aimed at encouraging more generic competition for brand-name drugs, Hatch-Waxman also established new incentives for innovation for brand-name drug manufacturers. For example, innovators can receive additional periods of patent protection through what is known as patent-term restoration. This provision in effect extends the life of a patent on a drug by up to five years to compensate for some of the time that the innovator company spends conducting human clinical trials on the drug before it has formally applied to the FDA for approval of the drug through a so-called New Drug Application-and also for the time the New Drug Application is under review.

Another form of incentive that innovator companies received is data exclusivity, which runs concurrently with patent protection. Data exclusivity restricts the FDA from approving a generic application that relies on a brand-name drug's safety and efficacy data for five years following that drug's approval.

Under Hatch-Waxman, therefore, market exclusivity for an innovative new drug depends on, among other factors, the combined impact of provisions that are designed to facilitate earlier entry into the market for generic drugs and other provisions that maintain incentives for innovation, as well as entry decisions by generic manufacturers.

There are strong economic incentives for generic firms to challenge patents in the hope of gaining competitive advantage over other generic manufacturers. During the 180-day exclusivity period, the first firm to market a generic form of a drug typically provides only limited price discounts compared to the brand-name drug and thus earns substantial revenues and profits. It also may benefit from a "first mover" advantage, meaning that even when price is matched, the first generic manufacturer may be likely to capture a higher share of the market. ${ }^{3}$ After the 180-day period ends, multiple generics typically enter the market and rapidly drive down prices and profits.

In its decision to file a Paragraph IV challenge, a generic manufacturer does not need to successfully defend the patent infringement lawsuit in court, and generics can receive exclusivity even if the case is settled. ${ }^{4}$ As a result, the potential for substantial economic gains can lead a generic manufacturer to challenge a patent even if the likelihood of successfully defending the challenge in court is relatively low.

\section{Prior Economic Studies}

Various economic studies have investigated the characteristics of generic competition following implementation of the Hatch-Waxman Act. ${ }^{5}$ These studies observed a distinctive pattern of market competition.

First, more generic versions of a drug generally led to greater generic price discounts and higher market share for the generic versions collectively.

Second, brand-name drugs that had high revenues tended to attract more generic versions. So did drugs that were easier to manufacture and that could more quickly satisfy FDA regulatory requirements, compared with more complex oral tablets such as conjugated estrogens, or other formulations such as patches, specially engineered capsules, or injected or inhaled products.

Third, brand-name firms seldom used pricing or promotional strategies to deter generics from entering the market. Rather, the firms typically curtailed or eliminated their promotional expenditures just prior to generic entry ${ }^{6}$ and maintained or increased their prices after generic entry occurred. ${ }^{7,8}$

Managed care firms and public payers have made the use of generic drugs a central costsaving strategy by imposing tiered formularies with lower copayments for generics than for brand-name drugs and by employing other incentives, such as restricting formulary coverage to generics in certain therapeutic categories., ${ }^{9,10}$ Pharmacies' margins over their acquisition costs for generics have been found to be higher than those for brand-name drugs, while the dollar amounts of the markup for generics and brand-name drugs are similar. ${ }^{11}$

The use of generics has increased substantially since the mid-1990s, in part because of the formulary incentives described above. In addition, numerous state laws allow generic forms to be substituted automatically by pharmacists for brand-name drugs prescribed by physicians. As 
a result, between 1994 and 2009 generic products' share of total prescriptions in the United States more than doubled, from 36 percent to 75 percent. ${ }^{1}$ The estimated cost savings to consumers from generic substitution also increased dramatically over this period. ${ }^{12}$

The impact of Hatch-Waxman on incentives to innovate has received less attention in the economics literature. A 1998 report by the Congressional Budget Office estimated that generic competition reduces by 12 percent the net present value of the total stream of future profits expected from the average brand-name drug. In particular, the Congressional Budget Office found that for brand-name drugs, the negative effects on returns from generic competition probably outweighed the positive effects of patent-term restoration, described above. ${ }^{13}$ More recently, Henry Grabowski and Margaret Kyle found that new drugs with patent challenges experienced shorter market exclusivity, all else being equal, and that the length of market exclusivity of blockbuster products has declined over time. ${ }^{14}$

The research presented here extends prior economic analyses by calculating the average market exclusivity for all new drugs facing initial generic competition between 1995 and 2008. We also consider trends in the likelihood and timing of patent challenges and the pattern over time of brand-name drugs' market-share erosion following generic entry for this comprehensive sample of new drugs.

\section{Study Data And Methods}

DEFINING 'MARKeT EXCLUsivity' Consistent with prior research, we defined market exclusivity as the time between the launch of a brand-name drug and the launch of its first generic competitor. This definition reflects the often complex interaction among many technical, regulatory, and competitive factors. These factors include the timing of patent filings, the amount of patent term lost during product development, the duration of regulatory review before FDA approval, the eligibility for patent-term restoration under Hatch-Waxman, the likelihood and outcome of generic patent challenges (including the possibility of a stay on generic entry for up to thirty months pending court decisions on patent infringement suits), entry decisions by generic manufacturers, and the duration of FDA review of generics. Any one or a combination of these factors can affect the market exclusivity of a particular drug.

MARKET EXCLUSIVITY DATA IMS Health, which maintains extensive pharmaceutical data, provided data for calculating market exclusivity for drugs experiencing first generic entry between January 1995 and December 2008. The data set used in the analysis contained information about all 332 drugs experiencing first generic entry in this period, including $200 \mathrm{com}$ pletely new products and 132 new formulations of older drugs. ${ }^{15,16}$ Our analysis focused on new products because regulations for generic entry differ if the brand-name product is a new formulation. However, the findings for new products were consistent with the findings for new formulations.

In addition to providing the information necessary to calculate market exclusivity, the data also included information on drug characteristics, such as mode of administration and number of generic entrants. All sales data are shown here in 2008 dollars, adjusted using the Department of Labor's Consumer Price Index for All Urban Consumers as the market deflator.

Our sample from IMS Health is a comprehensive universe of the new drugs that faced initial generic competition in the period 1995-2008. It should be noted, however, that in addition to generic competition, new drugs also face the prospects of therapeutic or "brand to brand" competition. As a result, some products in our sample might already have experienced a decline from their peak sales before generic competition began, because of both new product introductions by competing manufacturers and nextgeneration products from the original manufacturer.

Although this may have been the case, many of the products in our sample-including Prozac, Imitrex, Zocor, Neurontin, and Ambien-were among the market leaders in their therapeutic class when generic competition began. This paper does not present an analysis of the indirect impact of generic entry on other brand-name drugs with different active ingredients in the same therapeutic category, given the limited data on all of these brand-name alternatives.

PARAgRAPH IV CHALLENGES AND DATA As noted above, the Hatch-Waxman Act provides incentives for generic manufacturers to challenge patents, thereby shortening average market exclusivity for brand-name drugs. After the fourth year following a brand-name drug's approval as a new product, generic manufacturers can file an Abbreviated New Drug Application with a Paragraph IV certification that either challenges the patents protecting the brand-name drug or claims that the generic does not infringe on the existing patents. The first generic manufacturers ${ }^{17}$ to submit a Paragraph IV filing and prevail, either in court or through a settlement, receive 180 days of exclusivity, during which time no other version of the drug approved 
through an abbreviated application can enter the market. $^{18}$

We supplemented the market exclusivity data with a detailed review of information from the FDA's website on Paragraph IV filings. We also analyzed Abbreviated New Drug Application approval letters in the study period and searched other public information to identify all of the drugs in the data set that experienced Paragraph IV filings and the date of the first filing for each drug. Our data contained only drugs that experienced generic entry.

SALES DATA WITH GENERIC COMPETITION FOr the subset of drugs in our sample that experienced first generic entry between 1999 and 2008 , IMS Health provided additional data to enable us to calculate the monthly erosion of brand-name drugs' market share for the twelve months following first generic entry.

That erosion has greatly accelerated over the past decade, reflecting the growing impact of payer, pharmacist, and patient incentives to use generics. The copayment differentials between generics and brand-name drugs in insurance plans have increased over time to encourage patients to select the lower-cost alternatives. In some cases, insurers may choose not to cover brand-name drugs at all when a generic is available. Other formulary restrictions such as prior authorization and step therapy requirements also may apply to brand-name drugs in a therapeutic class.

\section{Study Results}

AVERAge NUMber OF Generic COMPetitors

Exhibit 1 presents the average number of a brand-name drug's generic competitors in the market one year after the first generic entry, segmented by level of sales and by time period for all of the new drugs in the data set. The number of generic entrants is far higher for drugs with larger sales before the first generic entry and for drugs more recently experiencing the first generic entry.

For example, drugs with over $\$ 1$ billion in annual sales prior to generic entry that experienced first generic competition in the period 1995-98 faced an average of six generic entrants after one year. By 2004-08, drugs with more than $\$ 1$ billion in annual sales faced an average of 10.1 generic entrants after one year. Similar increases in generic entry were experienced for drugs with under $\$ 1$ billion in sales.

AVERAGE PERIOD OF MARKET EXCLUSIVITY Exhibit 2 shows the average length of market exclusivity for all new drugs and for those with annual sales greater than $\$ 100$ million (in 2008 dollars). Between 1995 and 2008, the average market exclusivity periods for all new drugs were between 12.4 and 13.7 years. The average length of exclusivity was 12.4 years in the most recent period in our study (2007-08), compared to 13.5 years in the initial period (1995-96). ${ }^{19}$

New drugs with annual sales greater than $\$ 100$ million represent 95 percent of sales for all new

\section{EXHIBIT 1}

Average Number Of Generic Pharmaceutical Entrants, One Year After First Generic Entry, By Sales Volume, 1995-2008

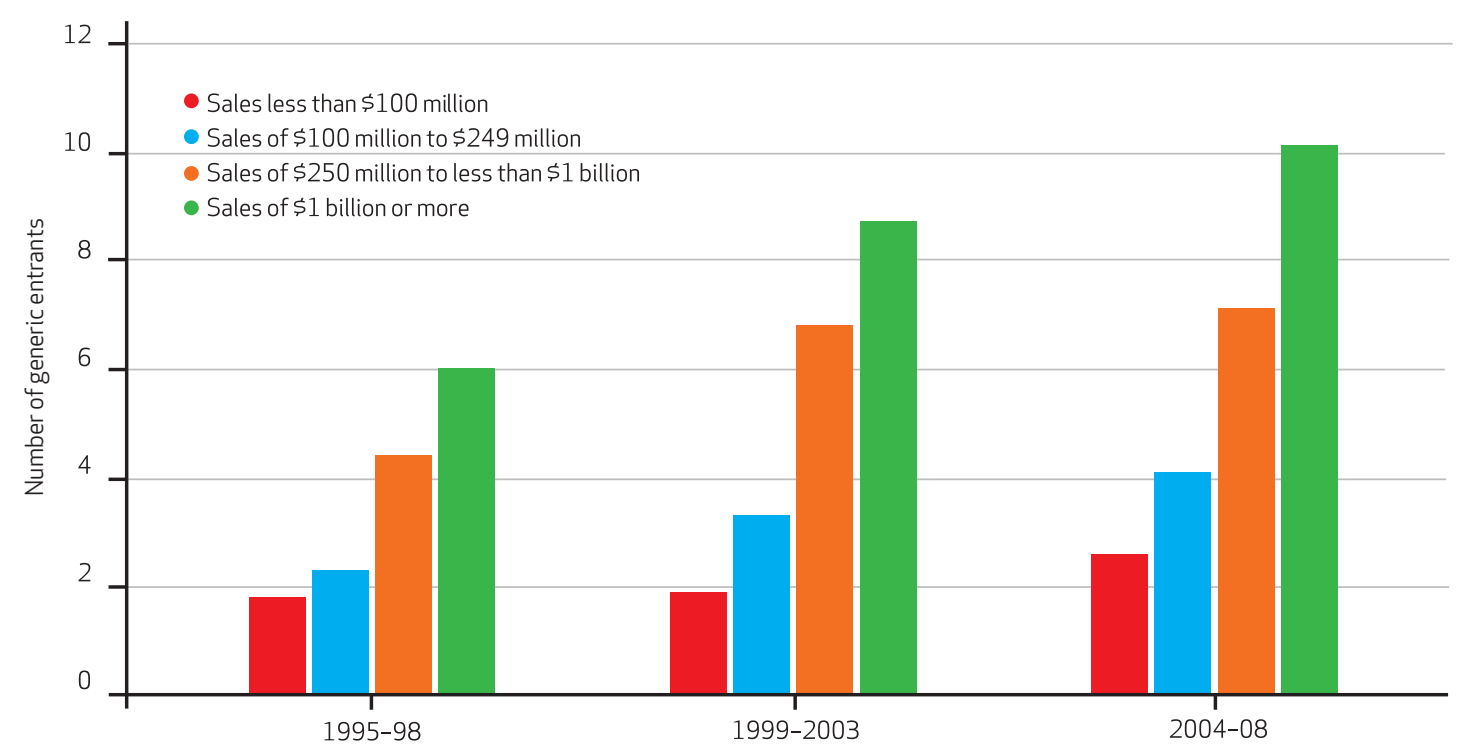

SOURCE IMS Health data on all new drugs with first generic entry in the period 1995-2008. Nore Annual sales are for the year preceding first generic entry and were adjusted using the Consumer Price Index for All Urban Consumers to reflect 2008 dollars. 


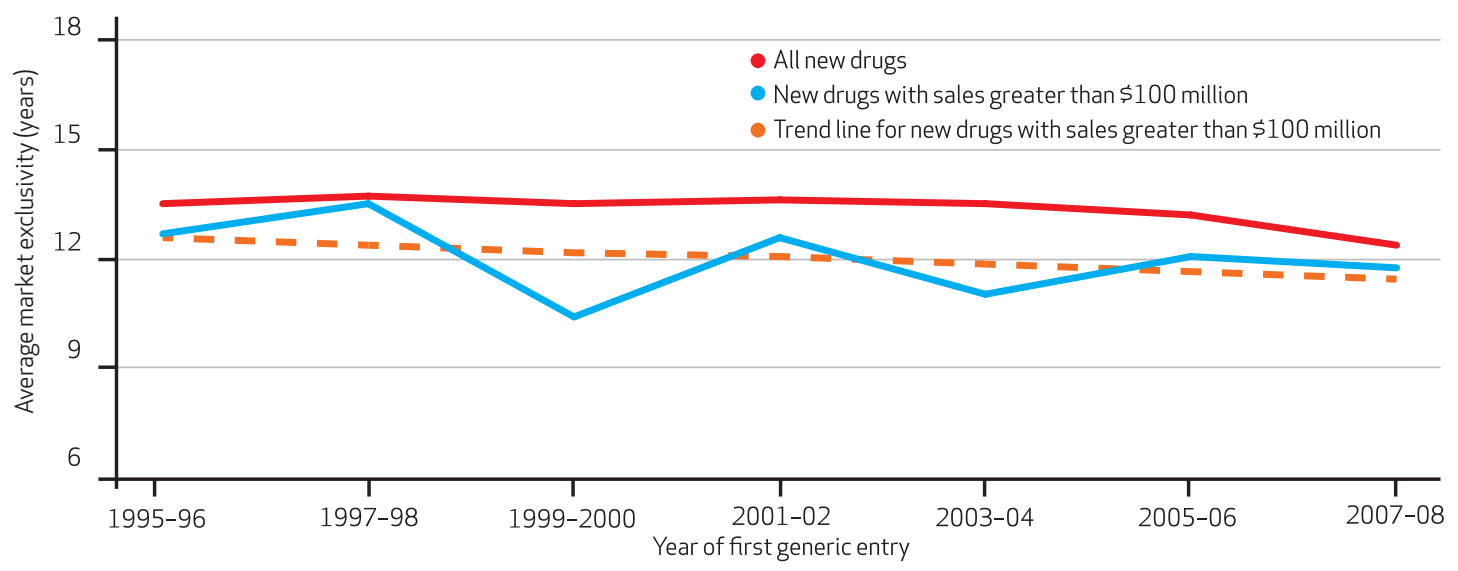

SOURCE IMS Health data for all new drugs with first generic entry in the period 1995-2008. Nores Sales are for the year preceding first generic entry and adjusted using the Consumer Price Index for All Urban Consumers to reflect 2008 dollars. The trend line for new drugs with annual sales greater than $\$ 100$ million was estimated based on a linear regression of average market exclusivity on the time period.

drugs in our data set experiencing generic entry. Average market exclusivity periods for these high-revenue drugs are shorter than for all new drugs (Exhibit 2). ${ }^{20}$

Our findings on the trends in length of market exclusivity were generally consistent with prior research. ${ }^{21}$ That earlier analysis also found that higher sales before generic entry and patent challenges were associated with shorter market exclusivity.

PARAgRAPH IV CHALLenges The frequency and speed of Paragraph IV challenges has increased rapidly in recent years (Exhibit 3). Only 9 percent of new drugs experiencing first generic entry in 1995 also experienced a Paragraph IV challenge at any point, but that share increased to 64 percent for drugs experiencing first generic entry in 2008. New drugs with sales greater than $\$ 100$ million (in 2008 dollars) faced an even higher probability of a Paragraph IV filing, increasing from 17 percent in 1995 to 75 percent in 2008 (data not shown).

\section{EXHIBIT 3}

Percentage Of New Drugs Experiencing Paragraph IV Challenges And Average Time From Launch To First Challenge, 1995-2008

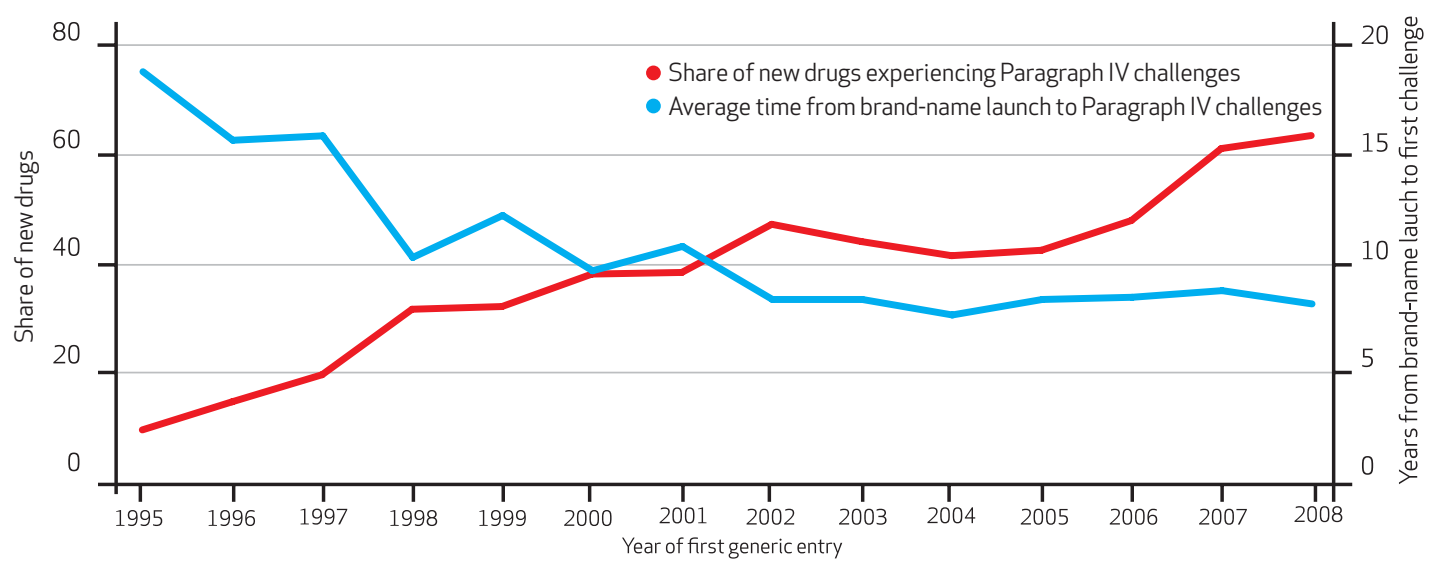

SOURCES IMS Health data for all new drugs with first generic entry in the period 1995-2008. Food and Drug Administration website data and general public information sources on Paragraph IV challenges. Notes All numbers are three-year moving averages. For example, average values reported for 1996 reflect the average for drugs experiencing first generic entry in 1995, 1996, and 1997. Share of new molecules experiencing Paragraph IV challenge is represented by the red line and relates to the left-hand $y$ axis. Average time from brand launch to Paragraph IV challenge is represented by the blue line and relates to the right-hand $y$ axis. 
Paragraph IV challenges are also occurring sooner following the launch of a brand-name drug. For new drugs experiencing first generic entry in 1995 and also experiencing a Paragraph IV challenge, the average time between launch and the first challenge was 18.7 years (Exhibit 3). That time fell to 8.2 years in 2008 . For new drugs with sales greater than $\$ 100$ million (in 2008 dollars), the average time between brand launch and first Paragraph IV challenge fell from 14.3 years in 1995 to 8.4 years in 2008 (data not shown). ${ }^{22}$

The calculations shown in Exhibit 3 were based on averages across all new drug introductions in a particular year and reflect a combination of various factors. These include the drug's sales prior to generic entry; the nature of the patents protecting the drug-for example, whether it is protected by patents on the drug itself, the manufacturing process, or the method of use-and the ease with which generic manufacturers can imitate the drug to satisfy FDA regulations.

For drugs with lower sales, generic firms are likely to be more selective in the patents they challenge. They will consider the estimated likelihood of prevailing in a challenge of the drug patents' invalidity and noninfringement, as well as other factors. However, as annual revenues increase to several hundred million dollars, generic manufacturers are more likely to use a "prospecting strategy" and file challenges. This is because even a low likelihood of success typically yields a large expected return on the investment necessary to challenge a patent.

A recent paper by Laura Panattoni examined district court litigation outcomes for Paragraph IV challenges filed prior to $2005 .{ }^{23}$ She found that Paragraph IV court decisions involved a disproportionate share of high-revenue drugs (although many drugs with lower sales were also involved) and drugs whose exclusivity period was long relative to the average length of patent protection. Generic firms won slightly more than half of the seventy-two district court decisions in her sample. She also found that Paragraph IV decisions have considerable consequences for brand-name drug manufacturers' market capitalizations and correspondingly may affect research and development incentives.

Ernst Berndt and others have provided evidence that the rate of Paragraph IV filings has continued to increase substantially in recent years, with ninety drugs facing Paragraph IV challenges between 2003 and 2005. ${ }^{24}$ Our analysis did not include the more recent challenges where generic entry had not yet occurred. An important area for future research is the impact

\section{Market-share erosion occurred more quickly for new drugs with sales greater than \$100 million.}

on market exclusivity and on research and development incentives, as these challenges become more frequent and are filed earlier. ${ }^{25}$

MARKET-SHARE EROSION AFTER GENERIC ENTRY The evolution of generic competition over the past decade has had a dramatic impact on the market share of brand-name drugs following generic entry. Exhibit 4 shows the erosion in brand-name drugs' share for the twelve months following first generic entry for all new drugs, defined as the unit share of brands divided by the sum of brands and their corresponding generics ("brand-name share"). On average, new drugs experiencing first generic entry in 1999-2000 maintained a share of 68 percent in the first full month of generic entry, declining to 44 percent at one year following first generic entry. ${ }^{26}$ But in 2007-08, new drugs retained a brand-name share of only 37 percent in the first full month of generic entry, which declined rapidly to 19 percent at six months and then more slowly to 15 percent at one year.

Erosion occurred more quickly for new drugs with sales greater than $\$ 100$ million. In 2007-08 their average brand-name share was 33 percent in the first month of generic entry, 18 percent at six months, and 13 percent at one year (data not shown).

\section{Discussion}

THE IMPACT OF HATCH-WAXMAN Increased generic competition over the past decade is reflected in greatly reduced market shares for brand-name drugs following first generic entry. More drugs also face patent challenges, and these occur earlier after product launch than in the past. The average length of market exclusivity ranged from 12.4 years to 13.7 years between 1995 and 2008 (Exhibit 2), but rapidly increasing Paragraph IV challenges suggest that further reductions in market exclusivity may be experienced in the future. ${ }^{27}$

The trends observed reflect both demand- and supply-side factors. The increasing speed and 
Brand-Name Share For Drugs, By Months After First Generic Entry, 1999-2008

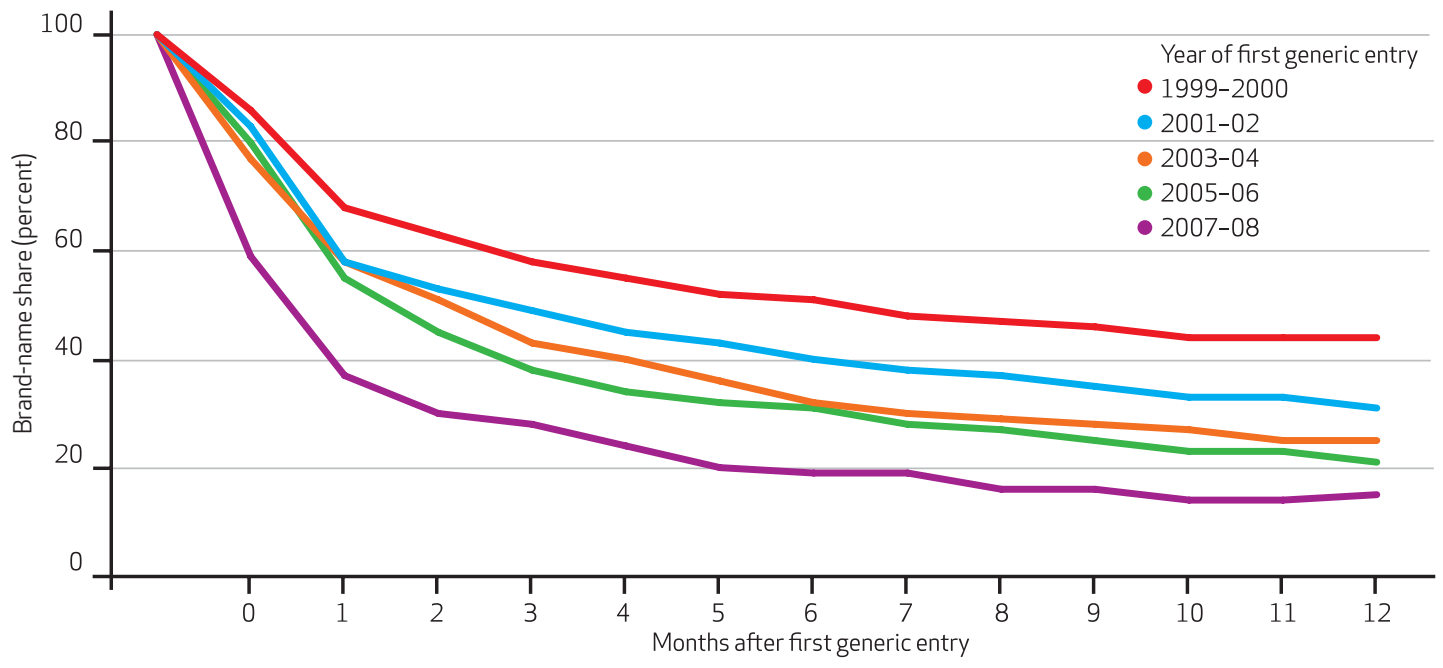

SOURCE IMS Health data for all new drugs with first generic entry in the period 1999-2008. Nores The first generic entry occurs at some point during month 0 . Month 1 is the first full month of generic competition. Brand-name share is measured using IMS Health monthly standard units (the smallest common dose of a drug, typically defined as one tablet or capsule for a solid drug taken orally; $5 \mathrm{ml}$ for a syrup; and one ampoule or vial for an injected drug).

extent of generic penetration, with generics' prices quickly approaching the marginal cost of the products, makes the rewards of a 180day exclusivity period for successful patent challenges more important to generic manufacturers' earnings than in the past. ${ }^{28}$ The prospect of a successful patent challenge and its attendant exclusivity period has become the main factor in predicting a generic firm's stock market performance. ${ }^{29}$

Under the Hatch-Waxman Act, generic competition has become the main driver of declining prices for several highly prescribed drug classes, with major benefits to consumers. At the same time, the 180-day exclusivity period created by the act-with its substantial rewards to generic manufacturers who challenge patents early in the brand-name drug's life cycle-creates uncertainty about whether an appropriate payback on research and development investment can be earned by innovators and may lead to unintended longer-term consequences. ${ }^{30}$

The research and development period for pharmaceuticals is costly and risky, and it now typically lasts longer than a decade. Thus, there is a correspondingly lengthy period needed for the new drug to earn a positive risk-adjusted return on its research and development investment. ${ }^{31,32}$

The immediate future is likely to be particularly challenging for the pharmaceutical industry. Several products with large sales (including Lipitor, the best-selling anticholesterol drug) are scheduled to experience initial generic competition in the next few years. Many additional products that have large sales have outstanding patent challenges, and they may also be subject to generic competition in the near future. Various studies have found that research and development pipelines and new drug introductions have been insufficient to replace the loss of sales revenues to generic competition over the past decade, and this is likely to continue.

the ADVENT OF biosimilars Section 7002 of the Affordable Care Act of 2010 includes an abbreviated pathway for biosimilars-the corollary for biologics of generic competition for "small molecule" drugs. A biologic is a product such as a vaccine, blood or blood component, protein, or living cell that is created through a biologic process, instead of being chemically synthesized as lower-molecular-weight small-molecule drugs. The new law does not have a 180-day exclusivity period for successful patent challenges or a thirty-month stay on biosimilar entry. It does include a twelve-year exclusivity period for new biologics before a biosimilar can enter the market with an abbreviated filing relying on the innovator's data. ${ }^{33}$ This compares to a data exclusivity period of five years for new drugs under Hatch-Waxman (or seven and a half years, including the thirty-month stay on generic entry, if there are patent challenges).

In the European Union, both new biologics and new small-molecule drugs receive the same ten-year data exclusivity period-eight years be- 
fore a generic or biosimilar application can be filed, and two additional years before the application can be approved. A one-year extension may also apply to new indications constituting important clinical benefits. The European Union does not reward generic manufacturers for patent challenges or provide for automatic stays on generic entry.

In light of the changing competitive dynamics between innovative and generic drugs, Congress should review whether Hatch-Waxman is achieving its intended balance of cost savings and innovative incentives. For example, a recent article suggests amending Hatch-Waxman along the lines of the new law governing biosimilars by eliminating the reward for patent challenges and the automatic stay on generic entry, while also harmonizing the data exclusivity periods for new drugs with the twelve-year period that now exists for new biologics. ${ }^{34}$

Others have suggested more-targeted approaches, such as extending the data exclusivity period for first-in-class drugs or drugs that address areas of major public health needs. ${ }^{35}$ This

\section{Generic competition has become the main driver of declining prices for several highly prescribed drug classes.}

would increase research and development incentives by reducing the uncertainty associated with early patent challenges. It would also give innovators a known window of time during which to recoup the large up-front research and development costs of pharmaceuticals without worrying about imitative generic filings based on the innovator's safety and efficacy data.

This research was supported in part by

Pharmaceutical Research and

Manufacturers of America. The design,

analysis, and composition of the

analyses and manuscript were

conducted independently and entirely by

the authors, who are solely responsible

for any errors.

\section{NOTES}

1 Berndt ER, Aitken M. Brand loyalty, generic entry, and price competition in pharmaceuticals in the quarter century after the 1984 WaxmanHatch legislation. Int J Econ Bus. 2011;18(2):177-201.

2 Grabowski H, Vernon J. Longer patents for lower imitation barriers: the 1984 drug act. Amer Econ Rev. 1986;76(2):195-8.

3 Grabowski H. Are the economics of the pharmaceutical research and development decisions changing? Productivity, patents, and political pressures. Pharmcoeconomics. 2004;22(2 Suppl 2):15-24.

4 Food and Drug Administration, Center for Drug Evaluation and Research. Guidance for industry: 180-day generic drug exclusivity under the Hatch-Waxman Amendments to the Federal Food, Drug, and Cosmetic Act [Internet]. Silver Spring (MD): CDER; 1998 Jun [cited 2011 Oct 3]. (Procedural Guidance 5). Available from: http:// www.fda.gov/downloads/Drugs/ GuidanceComplianceRegulatory Information/Guidances/ ucm079342.pdf
5 For a survey of this literature, see the discussion and references in Grabowski H. Competition between generic and branded drugs. In: Sloan FA, Hsieh CR, editors. Pharmaceutical innovation: incentives, competition, and cost benefit analysis in international perspective. Cambridge: Cambridge University Press; 2007. p. 153-73.

6 Ellison G, Ellison SF. Strategic entry deterrence and the behavior of pharmaceutical incumbents prior to patent expiration [Internet]. Cambridge (MA): Massachusetts Institute of Technology; $2007 \mathrm{Apr}$ [cited 2011 Oct 3]. Available from: http://econ-www.mit.edu/files/ 1700

7 Frank RG, Salkever DS. Generic entry and pricing of pharmaceuticals. J Econ Manage Strategy. 1997; 6(1):75-90.

8 In the case of patent challenges, brand-name firms may employ an "authorized generic" strategy to capture some of the generic sales during the 180-day exclusivity period and moderate their losses. An authorized generic relies on the brand- name drug's New Drug Application and is either produced by the brandname manufacturer or licensed by it to another manufacturer. Because it is not approved through an Abbreviated New Drug Application, it is allowed to enter the market during the 180-day exclusivity period. Berndt ER, Mortimer R, Bhattacharjya A, Parece A, Tuttle E. Authorized generic drugs, price competition, and consumer welfare. Health Aff (Millwood). 2007; 26(3):780-99.

9 Berndt E. Pharmaceuticals in U.S. health care: determinants of quantity and price. J Econ Perspect. 2002;16(4):45-66.

10 Office of the Assistant Secretary for Planning and Evaluation. Expanding the use of generic drugs [Internet]. Washington (DC): ASPE; 2010 [cited 2011 Oct 26]. (ASPE Issue Brief). Available from: http://aspe.hhs.gov/ sp/reports/2010/GenericDrugs/ ib.pdf

11 Congressional Budget Office. Medicaid's reimbursements to pharmacies for prescription drugs [Internet]. Washington (DC): CBO; $2004 \mathrm{Dec}$ 
[cited 2011 Oct 3]. Available from: http://www.cbo.gov/ftpdocs/60xx/ doc6038/12-16-Medicaid.pdf

12 A recent study undertaken by IMS Health and published by the Generic Pharmaceutical Association found that the use of FDA-approved generics in the period 2000-09 saved the US health care system more than $\$ 800$ billion, with savings of approximately $\$ 140$ billion in 2009 alone. Generic Pharmaceutical Association. Savings achieved through the use of generic pharmaceuticals 2000-2009 [Internet]. Washington (DC): GPhA; 2010 Jul [cited 2011 Oct 3]. Available from: http:// www.prescriptionaccess.org/ 2010_Report_Generic_Savings_ GPhA.pdf

13 Congressional Budget Office. How increased competition from generic drugs has affected prices and returns in the pharmaceutical industry [Internet]. Washington (DC): CBO; 1998 Jul [cited 2011 Oct 3]. Available from: http://www.cbo.gov/ftpdocs/ 6xx/doc655/pharm.pdf

14 Grabowski H, Kyle M. Generic competition and market exclusivity periods in pharmaceuticals. Manage Decis Econ. 2007;28:491-502.

15 We excluded one product from the analysis because generic versions of it were subsequently withdrawn as a result of litigation following their initial entry.

16 New formulations include changes in the form of administration-for example, changing from an injection to a topical application-but not new dosages or new indications.

17 Paragraph IV challenges can be made at the dose or strength level. A generic manufacturer's 180-day exclusivity period applies only to the dose or strength for which that manufacturer was the first to file a Paragraph IV challenge.

18 Padden M, Jenkins T. HatchWaxman changes. Natl Law J. 2004;26(25):1-2.

19 This decline from 1995-96 to 2007-08 is not statistically significant, reflecting in part the considerable variation across individual drugs and the small sample size.

20 Average market exclusivity periods were similar whether we analyzed drugs with annual sales greater than \$100 million, \$250 million, or
$\$ 1$ billion (in 2008 dollars).

21 The 2007 study by Henry Grabowski and Margaret Kyle (see Note 14) reported an average market exclusivity period of 11.5 years for new drugs with first generic entry in 2005 and over $\$ 100$ million in annual sales (in 2005 dollars)-almost identical to the 11.8 years found in the calculations reported here for 2007-08.

22 Paragraph IV challenge activity is even more aggressive for new drugs with sales greater than $\$ 250$ million (in 2008 dollars). Of these drugs that experienced first generic entry in 2008, 92 percent also experienced a Paragraph IV challenge, and the average time from launch to first challenge was 7.7 years.

23 Panattoni LE. The effect of Paragraph IV decisions and generic entry before patent expiration on brand pharmaceutical firms. J Health Econ. 2011;30(1):126-45.

24 Berndt ER, Mortimer R, Parece A. Do authorized generic drugs deter Paragraph IV certifications? [Internet]. Boston (MA): Analysis Group; 2007 Apr 17 [cited 2011 Oct 4]. (Working Paper). Available from: http://www.analysisgroup.com/ uploadedFiles/Publishing/Articles/ PhRMA_Authorized_Generic_ Entry.pdf

25 A working paper by Hemphill and Sampat discusses outcomes of Paragraph IV challenges associated with different forms of patent protection. Hemphill CS, Sampat BN. Evergreening, patent challenges, and effective market life in pharmaceuticals. [Internet]. New York (NY): Columbia Law School; 2011 May 3 [cited 2011 Oct 14]. (Columbia Law and Economics Working Paper No. 399). Available from: http://papers .ssrn.com/sol3/papers.cfm? abstract_id=1830404\#\#

26 Monthly sales data were not available for drugs experiencing first generic entry prior to 1999 .

27 Some legal experts believe that the bar for successfully challenging a patent on obviousness grounds was lowered in 2007 by the Supreme Court's decision in KSR v. Teleflex. Kunin SG, Beverina AK. KSR's effect on patent law. Michigan Law Review: First Impressions. 2007;106:50-54.

28 Generic firms race to be the first filer and gain the 180-day exclusivity. For successful brand-name drugs, the generic first filer can realize several hundred million dollars or more in the immediate years after generic launch. See Note 4.

29 Teva notes that "our revenues and profits are closely tied to our ability to obtain U.S. market exclusivity for generic versions of significant products." Teva Pharmaceutical Industries. Annual report. Petach Tikva (Israel): Teva; 2009. p. 5.

30 The focus here is on investment in innovative research and development, and our point is distinct from Adam Jaffe and Josh Lerner's general argument that there has been a proliferation of patents for trivial or nonexistent innovations. Jaffe $\mathrm{AB}$,

Lerner J. Innovation and its discontents: how our broken patent system is endangering innovation and progress, and what to do about it. Princeton (NJ): Princeton University Press; 2004.

31 Grabowski H, Vernon J, DiMasi JA. Returns on research and development for 1990s new drug introductions. Pharmacoeconomics. 2002; 20(Suppl 3):11-29.

32 Grabowski H. Follow-on biologics: data exclusivity and the balance between innovation and competition. Nat Rev Drug Dis. 2008;7(6): 479-88.

33 Grabowski H, Long G, Mortimer R. Implementation of the biosimilar pathway: economic and policy issues. Seton Hall Law Rev. 2011; 41(2):511-57.

34 An initial analysis of the economic trade-offs involving an adoption of this policy option by Dana Goldman and colleagues found that it would increase drug innovation and societal welfare over the long run but would also have short-run distributional effects. Goldman DP, Lakdawalla DB, Malkin JD, Romley J, Philipson T. The benefits from giving makers of conventional "small-molecule" drugs longer exclusivity over clinical trial data. Health Aff (Millwood). 2011;30(1): 84-90.

35 Higgins MJ, Graham SJ. Intellectual property: balancing innovation and access; patent challenges tip the scales. Science. 2009;326(5951): 370-1. 


\section{ABOUT THE AUTHORS: HENRY G. GRABOWSKI, MARGARET KYLE, RICHARD MORTIMER, GENIA LONG \& NOAM KIRSON}

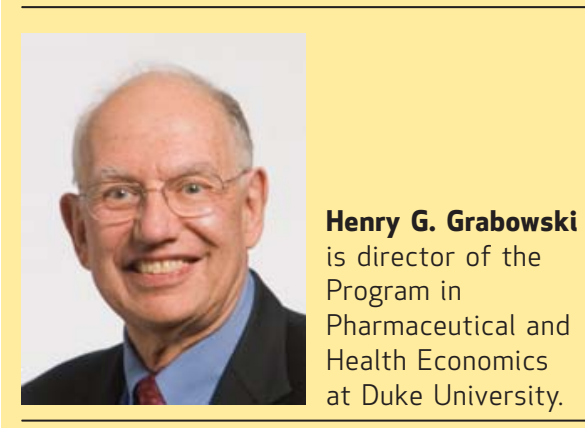

In this month's Health Affairs, Henry Grabowski and coauthors examine the impact of the HatchWaxman Act of 1984, which was intended to at once encourage costsavings in the pharmaceutical industry while also prompting innovation. The authors found a mixed result: While generic drug usage and challenges to brandname drug patents have risen, resulting in cost savings, they have also reduced incentives for innovators.

Henry Grabowski is a professor emeritus of economics and director of the Program in Pharmaceutical and Health Economics at Duke University. His research focuses on the economics of innovation, business regulation, and industrial organization. He has also investigated the economics of pharmaceutical research and has been an adviser and consultant to several organizations including the National Academy of Sciences, Institute of Medicine, Federal Trade Commission, and Office of Technology Assessment. Although at Duke since 1972, he has also served on the faculty of Yale University. He earned a doctoral degree in economics from Princeton University.

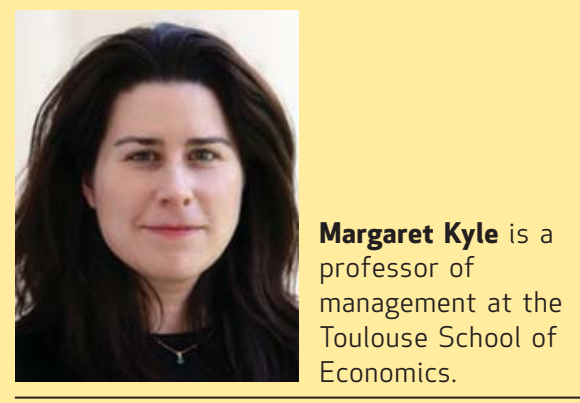

Margaret Kyle is a professor of management at the Toulouse School of Economics, in France. She concentrates on research and development productivity in the pharmaceutical industry, policies affecting the diffusion of new products, and the topic of this paper: generic competition. She also studies innovation and access to therapies in developing countries. Kyle earned a doctorate in economics from the Massachusetts Institute of Technology.

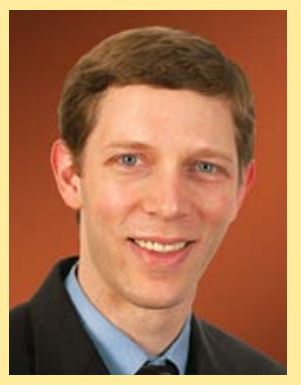

Richard Mortimer is a vice president at Analysis Group.

Richard Mortimer is a vice president at Analysis Group, a consulting firm specializing in applied economic research and analysis for private- and publicsector clients. He conducts economic analyses of health care policy issues, focusing on incentives and competition in the biologics, small-molecule pharmaceutical, and medical device industries. He has also provided this expertise for government investigations of the health care and technology-based industries and for antitrust litigation. Mortimer received a doctorate in economics from the University of California, Berkeley.

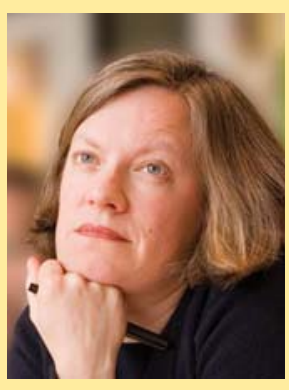

Genia Long is managing principal at Analysis Group

Genia Long is managing principal in the Boston office of Analysis Group. She performs economic analyses of firms' investment decisions, business strategies, and policies relating to innovation and competition in the health care industries. She earned a master's degree in public policy from Harvard University.

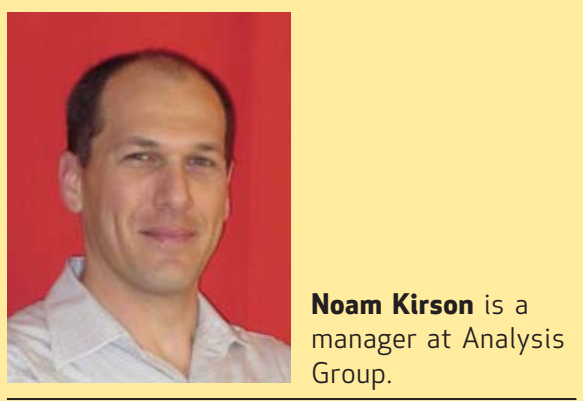

Noam Kirson is a manager at Analysis Group, specializing in the application of microeconomics and advanced statistical methods to litigation, health economics research, and business strategies. He has performed health outcomes studies for comparative effectiveness research, costeffectiveness evaluations, cost-ofillness studies, and the development of advanced modeling tools. Kirson received a doctorate in economics from Harvard. 